\title{
Erratum: The 2014 Beatson international cancer conference: powering the cancer machine
}

\author{
Jurre J Kamphorst and Daniel J Murphy ${ }^{*}$
}

\section{Erratum}

After publication of this Meeting Report [1], it emerged that sufficient permissions had not been granted to publish a particular section of the article. The relevant text has been replaced with:

Anne Brunet (Stanford University) discussed the metabolic regulation of aging using the $C$. elegans model. She focused on histone methylation as deficiencies in trimethylation of histone 3 at lysine 4 (H3K4me3) were found to increase lifespan. Regulation of H3K27me3 was also involved in lifespan determination. Brunet further discussed the importance of fat metabolism, in particular the different type of fatty acids, in H3K4me3-deficient worms and how this relates to longevity.

We apologise for any inconvenience.

Received: 16 December 2014 Accepted: 16 December 2014

Published online: 23 December 2014

\section{Reference}

1. Kamphorst JJ, Murphy DJ: The 2014 Beatson International Cancer

Conference: Powering the Cancer Machine. Cancer and Metabolism 2014 2:25.

\section{doi:10.1186/s40170-014-0127-8}

Cite this article as: Kamphorst and Murphy: Erratum: The 2014 Beatson

international cancer conference: powering the cancer machine. Cancer \& Metabolism 2014 2:127.

\footnotetext{
*Correspondence: Daniel.Murphy@glasgow.ac.uk

Cancer Research UK Beatson Institute and Institute of Cancer Sciences,

University of Glasgow, Garscube Estate, Switchback Road, Glasgow G61 1BD,
} UK

\section{Submit your next manuscript to BioMed Central and take full advantage of:}

囚Convenient online submission

$\bigotimes$ Thorough peer review

$\bigotimes$ No space constraints or color $₫$ gure charges

\Immediate publication on acceptance

囚Inclusion in PubMed, CAS, Scopus and Google Scholar

$\otimes$ Research which is freely available for redistribution

Submit your manuscript at

www.biomedcentral.com/submit

() Biomed Central

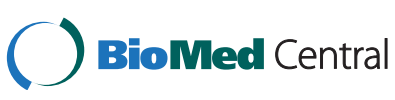

